\title{
Physical Crop Postharvest Storage and Protection Methods
}

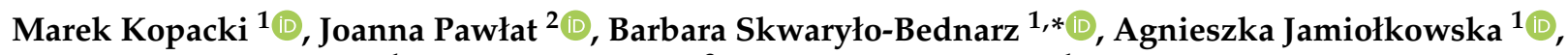 \\ Patrycja Maria Stępniak ${ }^{1}$, Piotr Kiczorowski ${ }^{3}$ and Katarzyna Golan ${ }^{1}$
}

1 Department of Plant Protection, University of Life Sciences in Lublin, Leszczyńskiego 7, 20-069 Lublin, Poland; marek.kopacki@up.lublin.pl (M.K.); aguto@wp.pl (A.J.); patrycjastepniak@onet.eu (P.M.S.); katarzyna.golan@up.lublin.pl (K.G.)

2 Institute of Electrotechnics and Electrotechnology, Lublin University of Technology, Nadbystrzycka 38C, 20-618 Lublin, Poland; askmik@hotmail.com

3 Department of Biological Bases of Food and Feed Technologies, University of Life Sciences in Lublin, Głęboka 28, 20-612 Lublin, Poland; piotr.kiczorowski@up.lublin.pl

* Correspondence: barbara.skwarylo@up.lublin.pl

Citation: Kopacki, M.; Pawłat, J.; Skwaryło-Bednarz, B.; Jamiołkowska, A.; Stępniak, P.M.; Kiczorowski, P.; Golan, K. Physical Crop Postharvest Storage and Protection Methods. Agronomy 2021, 11, 93. https:// doi.org/10.3390/agronomy11010093

Received: 10 December 2020 Accepted: 31 December 2020 Published: 6 January 2021

Publisher's Note: MDPI stays neutral with regard to jurisdictional clai$\mathrm{ms}$ in published maps and institutional affiliations.

Copyright: $(\odot 2021$ by the authors. Licensee MDPI, Basel, Switzerland. This article is an open access article distributed under the terms and conditions of the Creative Commons Attribution (CC BY) license (https:// creativecommons.org/licenses/by/ $4.0 /)$.

\begin{abstract}
Sustainable and organic plant production uses natural products and natural self-regulation processes occurring in the ecosystem. The awareness is growing and the demands of consumers are higher and higher. One solution is to use various methods, as an alternative to pesticides. It is also very important to care for the stored crops after harvesting especially using non-chemical methods. The physical method of plant protection consists in treating the harmful organism with physical factors such as temperature, its same light and radiation, controlled atmosphere, special packaging, pressure, various sounds, ozone, and low-temperature plasma. The availability of effective application techniques opens up new possibilities for the storage of crops in order to maintain their health and quality for a long time. This review focuses on the analysis of physical methods of postharvest protection, especially the latest methods using ozone and low-temperature plasma. As a result, consumers of agricultural crops will be able to consume food free of insects, mycotoxins and pesticide residues.
\end{abstract}

Keywords: physical methods; postharvest plant protection; ozone; plasma

\section{Introduction}

Currently, the main objective of plant protection in the European Union and in the world is to implement innovative and safe methods of limiting the development of pests in cultivations [1,2] and in the storage of agricultural and horticultural raw materials. This is related to the implementation of the concept of sustainable agriculture promoting the production of high-quality food in a socially responsible manner, rational use of natural resources and reduction of chemical plant protection product application [3-7]. It is also advisable to integrate various plant protection methods taking into account the requirements of environmental protection and human health [8,9]. The use of chemical plant protection products must be by the Code of Good Plant Protection Practice [10]. Too frequent and careless application of pesticides at various stages of production and during the storage of agricultural and horticultural raw materials contributes not only to the occurrence of resistant pest races, but also to environmental pollution and residue formation in the produced at then stored raw materials [11]. The goal of plant protection is not only to destroy harmful organisms or limit their activity but also to forecast the time they appear and the possible extent to which they might spread. Among the direct and indirect methods of plant protection, there are agrotechnical, biological, breeding, mechanical, quarantine, chemical, and physical methods [1,9]. Physical methods directly destroy harmful organisms, aim to retard their development or prevent them from spreading in the field and in the crop storage. 
One solution, instead of chemical methods, is to use various proven physical agents as an alternative to pesticides or use of known methods for new applications [12]. The physical method of plant protection consists in treating the harmful organism with physical factors such as temperature, radiation, light, controlled atmosphere, special packaging, pressure, various sounds and in recent years, also with effective and more and more frequently used thanks to greater availability and lower costs factors such as ozone and low-temperature plasma [13,14].

For the purposes of the article, the most used and economically justified elements of the physical method of plant protection are discussed, with a special emphasis on the more and more widespread, better researched and more accessible use of ozone and low-temperature plasma.

\section{Selected Physical Methods of Plant Protection Useful in Storage}

\subsection{Checked Solutions}

\subsubsection{Temperature}

The physical method utilizing low and high temperatures is primarily applied to control pests and pathogens. It is used for substrate decontamination, seed treatment, disinfection, or disinfestation, as well as for reducing the number of pathogenic microorganisms during fruit and vegetable storage $[15,16]$. It is also used for thermotherapy of plants infected with viruses.

The selection of appropriate temperature range for thermotherapy should allow the treated plant to survive and at the same time inactivate the virus, resulting in the production of virus-free plants [17]. Both high temperature, e.g., $37-40^{\circ} \mathrm{C}$, for control of Grapevine leafroll-associated virus 1 (GLRaV-1) and Grapevine rupestris stem pitting-associated virus (GRSPaV), a difficult to eradicate virus, from grapevine "Agiorgitiko" [17], as well as low temperature, approx. $5^{\circ} \mathrm{C}$, in chrysanthemum production free from Chrysanthemum stunt viroid (CSVd) are applied [18].

The use of low temperature is one of the most frequently used physical factors in the postharvest strategy of counteracting pathogen growth and the occurrence of fruit and vegetable pests [19]. Ventilation with cold air of low humidity, e.g., in warehouses or the freezing of agricultural and horticultural raw materials, often does not destroy pathogens and pests, but inhibits their spread, development and feeding. This process also reduces or even prevents the production of mycotoxins [20]. Therefore, such postharvest treatments are necessary to minimize pests occurrence and reduce the risk of contamination of fresh fruits and vegetables with pathogens [21]. Low temperature has been also successfully utilized to reduce pests of the ethnographic collections of the National Museum of the American Indian [22].

The use of high temperature in greenhouses and foil tunnels (even above $90{ }^{\circ} \mathrm{C}$ ) provides very good results in the control of crop pests and pathogens $[9,23]$, as well as in seed disinfection. However, it should be noted that it is dangerous for soil microflora, therefore it is recommended to use temperatures up to $60^{\circ} \mathrm{C}$, at which most pathogens die, and the antagonistic microflora is able to regenerate [9]. Water at a temperature of $43-44{ }^{\circ} \mathrm{C}$ is used to immerse planting material (e.g., seedlings, tubers, rhizomes, and bulbs) of various plants in order to destroy fungi, nematodes, and mites [13]. There are also known thermal seed disinfection methods at various time points against 74 viruses, rickettsiae, mycoplasmas, and fungi. Research showed that soaking soybean seeds of the cultivar MFS561 in hot water at a temperature of $60^{\circ} \mathrm{C}$ for $2 \mathrm{~min}$ significantly reduced contamination with pathogenic fungi [24]. High air or water temperature is used for thermal weed control, it is especially recommended for young weeds [25].

\subsubsection{Physical Radiation or Something}

Radiation is one of the non-traditional techniques of reducing pathogenic microorganisms and pests in food products, while maintaining nutritional value, without changing the quality attributes (flavor, odor, and color) [26]. Irradiation techniques can alter food chemi- 
cal composition and nutritional value, but these changes are usually minor and depend on food composition, irradiation dose and factors such as temperature and the presence or absence of oxygen in the radiation environment [26]. We distinguish various forms of radiant energy, emitted in various ways, which belong to the spectrum of electromagnetic radiation, and these include radio waves, microwaves, infrared radiation, visible light, ultraviolet light (UV), X-rays, and gamma rays [9]. There are two types of radiation in the electromagnetic spectrum: ionizing (X-rays and gamma rays) and non-ionizing radiation (radio waves, microwaves, infrared radiation, and visible and UV light [27]. Non-ionizing radiation, as a method of preserving horticultural and agricultural raw materials, is of little interest, in contrast to ionizing radiation [26]. Only a few studies have confirmed the use of different UV radiation wavelengths in reducing the occurrence of numerous pest species in greenhouse cultivations [28].

Currently, the use of ionizing radiation, i.e., radiation whose energy is sufficiently high to displace electrons from atoms and molecules and convert them into electric charges, called ions, is common in food processing [29]. Ionization occurs during radiation, which has a destructive effect on tissues of harmful microorganisms. The application of ionizing radiation, such as gamma radiation, in the protection of food products has many advantages (low energy requirements, similar changes in chemical composition as in other preservation methods), but also many barriers related to determining appropriate doses that cause death of pests, application costs and lack of information on food-induced radioactivity [30]. Gamma radiation is increasingly used to limit ornamental plants' 100 pathogen infections such as gray mold (Botrytis cinerea) on chrysanthemums [31]. The size of a given pest population can be significantly reduced when the appropriate dose is selected. Radiation also effectively destroys young larvae, eggs, and pupae. The study of Abbas et al. [32] showed that a dose of 400 Gray (Gy) for 1-24 h is sufficient to stop the hatching of larvae from the eggs of Indian meal moth Plodia interpunctella Hübner (Lepidoptera: Pyralidae), $300 \mathrm{~Gy}$ for 15 days to prevent the larvae from reaching adulthood, and 650 Gray (Gy) for 5 days to control population growth of this pest. Irradiation can be performed during product packaging for transport, storing unpackaged seeds in piles, seed accumulation at transhipment ports [32,33]. The radiation method is used to control pests and sterilize males by short-term irradiation, as performed in case of a fly of the order Callitroga-a dangerous parasite of farm animals in the USA in the 1950s [34].

Light traps to combat pests, with lamps emitting light of different spectrum, are based on the assumption that light has a strong influence on insect activity [35]. The effectiveness of a light trap can be improved by placing it in dark or dimly lit areas or places where pests gather [36]. The light is used to attract male moths of such pests as Autographa gamma, Agrotis ipsilon, and Tortricidae. Special devices with a light bulb inside are used for this purpose. There is a light source in the form of a light bulb inside this device. Thanks to this, it is possible to determine the number of harmful insects in a given cultivation and optimal date of plant protection treatments [37].

\subsubsection{Controlled Atmosphere}

Controlled atmosphere is increasingly used to limit the number of harmful organisms in storage facilities. For this purpose, special cold stores are built, in which it is possible to manage the atmosphere with specific parameters [38]. Such conditions are unfavorable for harmful organisms, and thus reduce their abundance [39]. Oxygen level (ULO) in the refrigerated room, where fruits and vegetables are stored, is significantly reduced (down to $5 \%$ ), which limits the number of pests [40] and maintains carbon dioxide content at a constant level. Conditions unfavorable to harmful organisms reduce their number, thereby facilitating crop storage $[39,41,42]$.

\subsubsection{Special Packaging}

Packaging materials differ in insect penetration resistance, although some insect species can penetrate most flexible films, foils, paper, and combinations. Polycarbonate foil 
is the most resistant polymer foil; polyester and polyester-urethane films are also resistant to penetration by insects [43]. The packaging is often made of many layers joined together, which increases the degree of protection against insects. Such a package usually includes paper, polyethylene foil, aluminum foil, polycarbonate, polyester, and polypropylene [9]. When using special packaging, it is important to select the right materials, taking account marketing requirements, including distribution and consumer needs, environmental issues and waste management [44].

\subsubsection{Pressure}

Reduced pressure is also applied to eliminate pests. Such a solution can be used in specially adapted rooms, from which air is sucked out and plant products are stored. This enables long-term storage of fruits and vegetables, and the lack of air eliminates pests [45].

\subsubsection{Various Sounds}

Sounds are often used to deter birds from causing damage to crops. Propane-butanefueled cannons or special devices with a loudspeaker are used for this purpose, most often emitting the sound of frightened birds [46]. This method is very effective and willingly used by fruit growers [47].

\subsection{Ozone and Non-Thermal Plasma}

\subsubsection{Ozone}

Ozone $\mathrm{O}_{3}$ is an allotropic form of oxygen made of 3 oxygen atoms and density of $2.14 \mathrm{~kg} \cdot \mathrm{m}^{-3}$. It was discovered by Schoenbain in 1839; in 1953 Trambarulo established ozone geometrical structure then Tanaka and Morino measured the ozone bond length of $0.126 \mathrm{~nm}$ [48-51]. Ozone in gaseous state is only partially soluble in water and its solubility decreases with increasing temperature [52].

The most important physical properties of ozone in comparison to oxygen are presented in Table 1.

Table 1. Comparison of some ozone and oxygen physical properties [48,53].

\begin{tabular}{ccccc}
\hline $\begin{array}{c}\text { Molecular } \\
\text { Weight }\end{array}$ & $\begin{array}{c}\text { Specific Gravity } \\
\text { in Temp. } \sim \mathbf{1 8 0}{ }^{\circ} \mathbf{C}\end{array}$ & $\begin{array}{c}\text { Freezing } \\
\text { Temperature }\left({ }^{\circ} \mathbf{C}\right)\end{array}$ & Boiling Point $\left({ }^{\circ} \mathbf{C}\right)$ & $\begin{array}{c}\text { Condensed } \\
\text { Gas Color }\end{array}$ \\
\hline ozone $\mathrm{O}_{3} 48.00$ & 1.570 & -192.8 & -111.9 & Dark blue \\
oxygen $\mathrm{O}_{2} 32.00$ & 1.118 & -218.9 & -182.9 & Light blue \\
\hline
\end{tabular}

Under normal conditions, ozone is a colorless gas with a pungent smell, while at very low concentrations (up to $0.04 \mathrm{ppm}$ ), it can give a feeling of pleasant freshness [54]. Ozone has a blue color when its concentration exceeds 15-20\% [48]. At an atmospheric pressure and a temperature of $161.3 \mathrm{~K}\left(-111.85^{\circ} \mathrm{C}\right)$, ozone becomes liquid and has a dark blue color (Table 2). Ozone becomes liquid at -193 to $-111^{\circ} \mathrm{C}$. As a liquid, it becomes red-violet in color and its boiling point is $-160^{\circ} \mathrm{C}$. It solidifies at $80.6 \mathrm{~K}\left(-193.15^{\circ} \mathrm{C}\right)$ and then acquires a dark purple color [55] (Table 2). It is formed naturally in the upper part of the Earth's atmosphere, at an altitude of about $30 \mathrm{~km}$, resulting from UV radiation, which breaks down the $\mathrm{O}_{2}$ molecules into individual atoms, which in turn bind other molecules of this gas [56]. In the gaseous state, its color is light blue (Table 2). Under laboratory conditions, ozone is produced with the involvement of UV light or in plasma reactors called ozonators or ozone generators.

Table 2. Ozone colors in dependence on state properties $[48,53]$.

\begin{tabular}{cc}
\hline State & Color \\
\hline solid & Red-purple \\
liquid & Dark blue (not transparent) \\
gaseous & Light blue (transparent in thin layer) \\
\hline
\end{tabular}


During decomposition, ozone releases a molecule and an oxygen atom, which reacts quickly with various chemical compounds leading to their neutralization. This reaction is called ozonation. It is characterized by a wide range and safety for the environment and people [54,57]. Ozonation is most often used for air purification in closed rooms [58]. Thanks to this process, the air becomes fresh, free of microorganisms-bacteria, viruses, and other substances that threaten human health [59].

Currently, in the era of coronavirus spread, ozonation will most likely be one of the most effective methods of physical disinfection of rooms, especially offices. Due to its disinfecting and sterilizing properties, ozone treatment is often used, e.g., in various doctor's offices, clinics, clubs, hotels, offices, and schools. It is also used for the disinfection of specific equipment, devices, facilities, for cleaning ventilation and air conditioning. Ozone, as an oxidant, is widely used in water treatment and disinfection-it eliminates unpleasant odors, flavors, and colors [54,60-62].

In addition, it is also used to neutralize $\mathrm{Fe}, \mathrm{Mn}$, ammonia, and hydrogen sulfide, and other chemical compounds in water $[63,64]$. Ozone has been proven to oxidize biological tissue as a result of a free radical process. Therefore, ozone is considered a radiometric agent [65].

Ozonation as a physical method is increasingly used in agriculture, horticulture, and their surroundings $[62,66]$. It is one of the most promising techniques in plant protection $[67,68]$, it is more effective and acts more rapidly than other solutions used so far. Raw materials and ozonated products do not lose their properties and do not have to be quarantined. Ozonation is considered an ecological method in disinfestation, disinfection, and deratization [69]. Ozone is often used for disinfestation of grain and storage rooms [70] and greenhouse cultivations to control 188 ornamental plants' pests of ornamental plants, especially quarantined ones [71]. It destroys spores of mites and insects [72,73]. It is also one of the most popular ways to fight household insects such as flies, mosquitoes, spiders, cockroaches, bedbugs, lice, mites, moths, ants, silverfish, and all kinds of larvae. Ozonation has been used to decontaminate soil to eliminate harmful microorganisms [73].

Currently, interest in ozonation during the storage and processing of fruit and vegetables is increasing each year [74-76]. Microbiological contamination of fruits and vegetables can occur at various stages after harvest from farm to fork [76]. Therefore, it is important to develop and implement an appropriate postharvest strategy for a specific yield of a given plant. Such a strategy should take into account the spread of microorganisms, which occur during field growth, harvesting, handling and postharvest transport, storage, processing, and marketing up to human consumption.

Washing fruits, e.g., strawberries, in an aqueous ozone solution before freezing reduces the amount of yeast and mold by up to $98 \%$, and saprophytic organisms by $95 \%$ [77]. Ozone is used not only to disinfect fruits, but also vegetables and fish [76]. Freshly sliced lettuce, thoroughly washed with ozone water, and then packed in ozone significantly increases the shelf life [78]. Importantly, immersing the lettuce in ozone-containing water (3 ppm) for up to $5 \mathrm{~min}$, followed by storage at $4{ }^{\circ} \mathrm{C}$ for nine days, has effectively inactivated Escherichia coli and Listeria monocytogenes, which increases food safety [79].

Ozonated water can also be used to eliminate pesticide residues in various fruits [80]. The study of Ong et al. [81] demonstrated that washing apples in ozone-containing water (25 ppm) for 30 min significantly reduced the level of pesticides on the applied surface. It should be noted that this method may be associated with a high risk of phytotoxicity; therefore, it cannot be used for extended time periods and with all plant species. Selection of the dose and time of plant ozone exposure is important. It is worth mentioning that ozone water shows high insecticidal activity and can be successfully used against pests in storage facilities [62].

Beuchat [82] showed that ozonation significantly reduced pathogen population, and thus had a positive effect on extending the shelf life of fresh vegetables such as broccoli, cucumbers, and fruits-apples, grapes, oranges, pears, raspberries, and strawberries. 
In the case of raspberries, ozonation extends the storage period even to four days [83], and apples up to three months [84]. Moreover, apple ozonation, apart from their much better healthiness, contributes to the reduction of fruit weight loss and possible waste generation [82]. Continuous exposure to ozone ( $0.3 \mathrm{ppm}(v / v)$-US-OSHA threshold value for short-term exposure) contributed to the inhibition of aerial mycelium growth and sporulation on lesions (wounds) of peaches cv. "Elegant Lady" inoculated with Monilia fructicola, Botrytis cinerea, Mucor piriformis, Penicillium expansum, and stored for four weeks at $5{ }^{\circ} \mathrm{C}$ and $90 \%$ relative humidity (RH) [85]. When peach fruits were returned to the ambient atmosphere, fungal growth and sporulation resumed. Ozone content of $0.3 \mathrm{ppm}$ in storage for a period of seven weeks at $5{ }^{\circ} \mathrm{C}$ was also effective in inhibiting the growth of Botrytis cinerea on table grapes of the cultivar "Thompson Seedless" [85]. Other studies demonstrated that the low ozone dosing process $(0.3 \mathrm{ppm})$ sufficiently reduced rotting of table grapes caused by Botrytis cinerea development, and thus provided a 40-day shelf life [86].

The effectiveness of ozone in reducing Botrytis cinerea on grapes was also confirmed by De Simone [87]. It is important that ozone fumigation did not change the color of the fruit and chlorophyll content. Ozone sanitation also provided good results in limiting the number of pathogens on stored pears, especially of the genus Penicillium, and Botrytis cinerea [88].

The development of fungal lesions caused by Alternaria alternata and Colletotrichum coccodes was limited by ozone concentration from 0.005 to $5.0 \mu \mathrm{mol} \cdot \mathrm{mol}^{-1}$ [89]. Onions exposed to ozone during storage had less mold and bacteria, and additionally their chemical and sensory composition did not change [90].

Ozone also induced biochemical defense mechanisms of wheat against Erysiphe graminis [91]. It caused very high mortality among aphids on lettuce, even at ultra-low oxygen concentration (ULO) [92]. Studies carried out in recent years have also confirmed the destructive effect of ozone on viruses dangerous to humans, including SARS-CoV-2 [93,94].

Unlike chemical plant protection products, ozone treatment does not result in residues formation in the natural environment and in agricultural and horticultural raw materials. It can be suggested that the popularity of this procedure will increase from year to year. Ozone application in farm buildings improves sanitary conditions and the stored product is more resistant to viral and bacterial infections. Ozone can quickly and safely remove unpleasant musty, burning, or animal odors.

Research confirms that viruses react faster to ozone action than bacteria. This is due to the fact that they have an envelope built of a large amount of lipids that easily react with ozone. Therefore, ozone can be successfully used against viral pathogens [95]. In bacteria, ozone first disrupts the cell wall and then causes fatty acid peroxidation. As a result, changes in the cell membrane occur, leading to the loss of viability or reproduction possibility of bacteria that cause numerous plant diseases. It effectively eliminates bacteria such as Listeria monocytogenes and Yersinia enterocolitica. Ozone is also used to neutralize iron, manganese, ammonia and hydrogen sulfide in water [96].

It should also be noted that tropospheric ozone formed in the atmosphere has a phytotoxic effect and is a secondary air pollution. It is formed in photochemical reactions with the participation of initiating substances, i.e., nitrogen oxides and volatile organic compounds (VOC) under high temperature and insolation [97,98]. Ozone is also becoming, unfortunately, the most important air pollutant next to sulfur dioxide and has a significant impact on the destruction of forest ecosystems in Europe, causing accelerated leaf aging and a decrease in chlorophyll content [99]. Therefore, it can, therefore, 259 under certain conditions, cause a phytotoxicity phenomenon, particularly visible on leaves and needles. Ozone reaction with cellular structures generates reactive oxygen species that cause denaturation of membrane lipids and their peroxidation, resulting in the so-called oxidative stress [100]. Ozone is also responsible for the impairment of stomata closure, which leads to excessive water loss through transpiration [101]. Above $0.1 \mathrm{mg} \cdot \mathrm{m}^{-3}$, high ozone concentration is very dangerous for human, animal, and plant organisms [102]. Staying in its presence can 
cause headaches and pain in the chest. It has mutagenic properties, so it can only be used in the absence of people or animals.

\subsubsection{Plasma}

Plasma, which also contains ozone, is often called the fourth state of matter due to its high energy potential. The moment of matter transition from gaseous to plasma is when the gas acquires charge-conducting properties and loses its insulating properties. Plasma is most often produced by means of electrical discharges in gases. Depending on the application, it is possible to model plasma parameters such as gas chemical composition, pressure, structure of the magnetic field and other elements influencing its structure. There are very reactive particles in the plasma stream, which, when passing from the excited state to the ground state, emit energy by photon emissions, e.g., ultraviolet light or by transferring energy to a cell they encounter $[103,104]$. The appropriate energy required to generate plasma causes the ionization of atoms and molecules [105]. Depending on the plasma-generating gas, reactive forms of oxygen and nitrogen may be formed, i.e., hydrogen peroxide, $\mathrm{OH}, \mathrm{OH}_{2}, \mathrm{NO}$ radicals, and ozone $\mathrm{O}_{3}$, as well as free electrons, ionized particles, and neutral particles [106-108].

Plasma is divided, among others, according to temperature, i.e., low-temperature and high-temperature plasma. In plant protection, low-temperature plasma, classified in terms of energy in the range from $0.2 \mathrm{eV}$ to $3 \mathrm{eV}$, is used. Temperature with such an energy involvement ranges from 2000 to $30,000 \mathrm{~K}$. This type of plasma is characterized by weak ionization and contains many neutral particles [103].

One of the first plasma generators were ozonizes, firstly constructed in 1875 by Siemens.

Most of ozone generators are based on the dielectric barrier discharge; however, in some constructions corona discharges are used. Ozone is easily created under the atmospheric pressure, when the dielectric barrier is present in the discharge gap between the electrodes and the source frequency ranges are about $50-60 \mathrm{~Hz}$ or $0.5-5.0 \mathrm{kHz}[109,110]$. At the atmospheric pressure, the microdischarges cover the electrode area rather uniformly; however, some chemical additives in the substrate gas or modification in the electrodes' material can further improve the discharge homogeneity [111]. Basing on the discharge geometry; the barrier discharges in the plasma generators can be classified as [112-115]:

- $\quad$ volume discharge-discharge column occurs in the gas gap and a surface discharge on dielectric;

- $\quad$ surface discharge, which occurs only on the surface of dielectric;

- coplanar discharge with one or more pairs of electrodes with the opposite polarity and a fixed electrode distance, located within a bulk of dielectric, assures the discharge's better uniformity.

In the recent years, the atmospheric pressure plasma jets (APPJ) have gained a lot of attention. They are able to produce homogenous plasma at the atmospheric pressure and post discharge gas has relatively low temperature. APPJs operate with variety of power sources of low-, radio- and microwave frequency. In order to attain low temperatures on the outlet of the nozzle-noble gases such as helium or argon are used with the additives of other reactive gases such as air, $\mathrm{O}_{2}, \mathrm{~N}_{2}, \mathrm{H}_{2} \mathrm{O}, \mathrm{CO}_{2}$, etc. [116-119]. Examples of flexible in operation and portable plasma jets are depicted in Figure 1. 
(A)

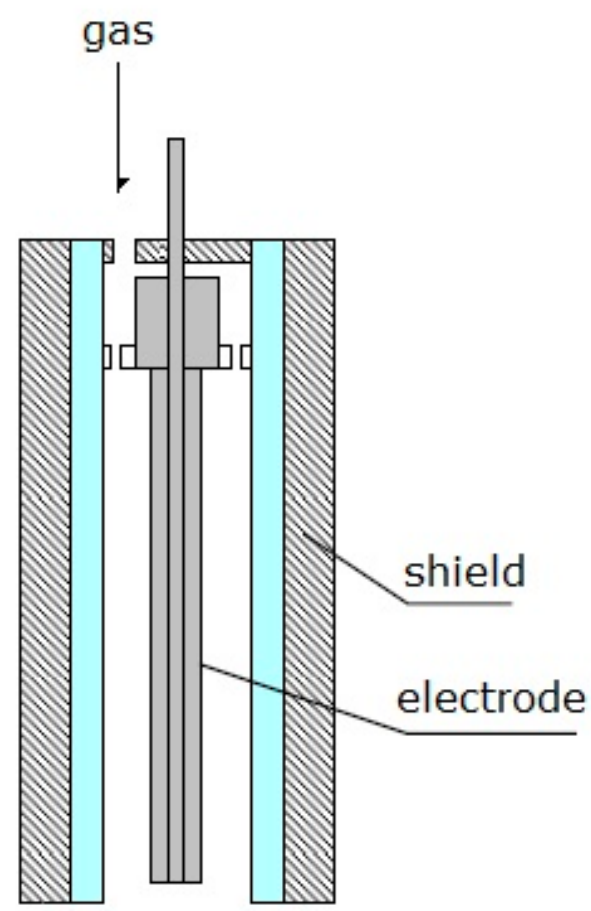

(B)

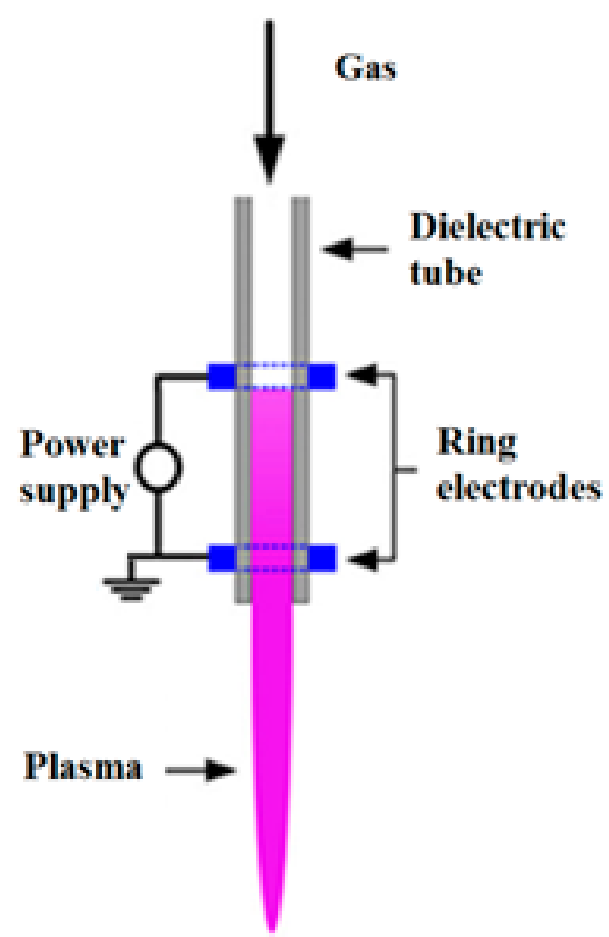

Figure 1. Schema of atmospheric pressure plasma jets: RF-type (A), DBD-type (B) $[104,118]$.

Another type of plastrons used for biological purposes is direct current driven selfpulsing transient spark (TS) discharge. Such a plasma generator can operate in air with water electrode or as a water spray system [120]. Gliding arc discharge (GAD) reactors are very flexible plasma sources, which can be supplied with any type of substrate gas, operate at high gas flowrates and generate variety of active species. However, the temperatures of the outlet gas are slightly higher then APPJs and for non-hear resistant materials they require longer distance between the gas outlet and sample [121,122].

Apart from physical factors accompanying plasma generation, chemically active particles produced in the plasma may participate in further chemical reactions, and have a destructive effect on microbial cells. As a result, plasma can be used in the treatment and decontamination of various surfaces of living tissues. The mechanism of plasma action on microorganisms is multistage and consists mainly of permanent damage to the cell wall, cytoplasmic membrane and subsequently intracellular structures, genetic material, and enzymatic apparatus $[123,124]$. This is appears to be a sentence fragment. Consider rewriting it as a complete sentence. Other researchers pointed to the accumulation of electric charges on membrane surface or pulsed electric field destruction of the plasmalemma [125]. Reactive forms of oxygen and nitrogen and hydroxyl radical neutralize pathogens and their spores. UV radiation, which occurs during plasma formation process, also has a sterilizing effect [126]. Such a strong plasma reactivity also various surfaces without the need to use invasive chemicals [127-129]. Plasma devices were originally created so that nothing but compressed air and electric current were needed in material pre-cleaning processes. This enabled very fast, thorough and electrostatic discharge elimination cleaning of material surfaces, which could later be permanently combined with other materials. During the cleaning process, the high energy plasma level disrupted the structure of organic substances contaminating the material and removed impurities from the surface [130]. Plasma is also used in the industrial production of nanomaterials $[131,132]$ and synthesis and application of thin coatings [133-135].

The application of low-temperature plasma to propagation material's health status is an innovative method in plant protection $[14,136]$. Cold plasma, when properly 
applied, mainly destroys pathogen cells without damaging the plant itself [137]. It is most often used for the treatment-decontamination and stimulation-of seed material and seedlings [14,138-142]. Plasma is also known to be effective in disinfecting bacteriainfected vegetables, fruits [143,144], and grains [145]. It has been proven that plasma can significantly reduce the number of bacteria of the genus Bacillus-dangerous pathogens of many plants [146]. It is also effective in reducing the number of bacteria harmful to humans, even strains resistant to antibiotics, causing their complete inactivation at ambient temperature $[147,148]$. It can also limit Escherichia coli and can be used for material sterilization and food conditioning [149-153]. There are numerous possibilities of using plasma in medicine, e.g., for the treatment of wounds, skin diseases, tissue regeneration and as a support in cancer therapy [144,154-158]. The so-called "plasma razor" is used in medicine to disinfect and control fungi dangerous for humans, such as Candida albicans and Prototheca zopfii [159]. The positive effect has been proven of hazelnut plasma treatment on the reduction of harmful to humans aflatoxins produced by Aspergillus flavus and $A$. parasiticus that have been one of the most dangerous contaminants in food products for years [160,161]. Plasma is also helpful in controlling harmful insects, e.g., of the genus Drosophila [162].

Cold plasma is used for sterilization of tools and disinfection of rooms in hospitals, food production plants and environmental protection. It can also be used for hygienization of municipal waste used for fuel production [163]. The effectiveness of using cold plasma depends on the type of device producing it, electric energy frequency, duration of a single excitation pulse, time of exposure of plant cells to the plasma and the work gas used [164].

The effect of plasma water on selenium availability in plants and photosynthesis parameters was also observed [165]. It was also shown that plasma affected the physicochemical parameters of deionized water [166] as well as photosynthesis process in cereal plants [167].

Physical factors may have a positive effect on physiological processes occurring in plants as well as in plant seedlings. The positive effect of plasma on the processes occurring in seeds is known [168-170]. Ways of accelerating new root formation are also still being sought. Chemical preparations that accelerate rooting have been known for years, but in recent years, the interest in alternative methods such as temperature, laser rays, ozone, or plasma has increased due to the limitations of chemical plant protection products [171,172]. The effect of low-temperature plasma on root morphology and nutrient uptake of tomato has also been recognized [173]. The positive effect of plasma on seed processes related to catalase action has been proven [174]. Many researchers have confirmed the positive effect of plasma on plant rooting process, especially the increase in the length and number of formed roots $[175,176]$. Plant hormones-auxins-are the most important chemical substances in the process of rhizogenesis [177]. These compounds are responsible, among others, for stimulating root production, they are secreted in the seedling growth apices, from where they are transported to lower root parts. Natural auxins include, for example, indole acetic acid (IAA) and indolylbutyric acid (IBA). Thanks to their action, the rooting process is usually faster, roots are longer, and the entire root ball is larger [178,179]. Despite the fact that auxins, responsible for cell development and differentiation, are formed inside the roots and can be produced by soil microorganisms or synthetically, the possibility of stimulating their production by biostimulators and foliar fertilizers [180] as well as external physical factors is being sought [181].

\section{Conclusions}

The use of chemical plant protection products is increasingly associated with numerous limitations. The result, i.e., from the introduction of the concept of sustainable agriculture or the integration of methods in pest control, whose purpose is primarily to protect the environment and human health. One solution in modern agriculture, especially in the storage of products such as seeds, vegetables, and fruits, is to use various non-chemical physical methods, including ozonation and non-thermal plasma. These are quick and 
effective physical agents for the control of pests responsible for postharvest diseases of crops and agricultural produce, and they do not leave residues in the environment and plant raw materials. Plasma, in addition to its direct disinfecting action, contributes to the stimulation of plant growth and the improvement of physiological processes occurring in plant cells. Larger and more rational use of the physical method of plant protection will in the future affect good habits in agriculture and storage, reduce the use of pesticides that have a negative effect on consumer health and have a positive impact on the environment. Social, economic, and environmental sustainability are closely intertwined and necessary components for a truly sustainable agriculture.

Author Contributions: Conceptualization, M.K. and J.P.; writing-original draft preparation, B.S.-B., J.P. and M.K.; writing-review and editing, A.J., P.K., K.G. and P.M.S.; visualization, B.S.-B., A.J., P.K., P.M.S., K.G. and M.K. All authors have read and agreed to the published version of the manuscript.

Funding: This review was funded by University of Life Sciences, project DS/OKK/s/44/2020.

Institutional Review Board Statement: Not applicable.

Informed Consent Statement: Not applicable.

Data Availability Statement: Not applicable.

Conflicts of Interest: The authors declare no conflict of interest.

\section{References}

1. Jamiołkowska, A.; Hetman, B.; Skwaryło-Bednarz, B.; Kopacki, M. Integrowana ochrona roślin w Polsce i Unii Europejskiej oraz prawne podstawy jej funkcjonowania. Ann. UMCS Sec. E Agric. 2017, 71, 103-111. [CrossRef]

2. Barzman, M.; Barberi, P.; Birch, A.N.E.; Boonekamp, P.; Dachbrodt-Saaydeh, S.; Graf, B.; Hommel, B.; Jensen, J.E.; Kiss, J.; Kuds, P.; et al. Eight principles of integrated pest management. Agron. Sustain. Dev. 2015. [CrossRef]

3. Mazur-Wierzbicka, E. The Application of Corporate Social Responsibility in European Agriculture. Misc. Geogr. 2015, 19, 19-23. [CrossRef]

4. Haladyi, A.; Trzewik, J. Pojęcie strategicznych zasobów naturalnych-Uwagi krytyczne. Przeglą Prawa Ochr. Sr. 2014, 1, 27-46. [CrossRef]

5. Gamliel, A. Application aspects of integrated pest management. J. Plant Pathol. 2010, 92, S4.23-S4.26. Available online: www.jstor.org/stable/41998884 (accessed on 12 November 2020).

6. Brühl, C.A.; Zaller, J.G. Biodiversity Decline as a Consequence of an Inappropriate Environmental Risk Assessment of Pesticides. Front. Environ. Sci. 2019. [CrossRef]

7. Valiuskaite, A.; Uselis, N.; Kviklys, D.; Lanauskas, J.; Rasiukevičiūtè, N. The effect of sustainable plant protection and apple tree management on fruit quality and yield. Zemdirb. Agric. 2017, 104, 353-358. [CrossRef]

8. Sorby, K.; Fleischer, G.; Pehu, E. Integrated Pest Management in Development: Review of Trends and Implementation Strategies; The International Bank for Reconstruction and Development Agriculture and Rural Development Department: Washington, DC, USA, 2003; p. 66.

9. Jaworska, M. Ochrona Środowiska i Ochrona Roślin; Wydawnictwo UR: Kraków, Poland, 2012; p. 379.

10. Kierzek, R.; Korbas, M.; Matyjaszczyk, E.; Mrówczyński, M.; Rosada, J.; Tratwal, A.; Węgorek, P. Kodeks Dobrej Praktyki Ochrony Roślin; Wyd. IOR: Poznań, Poland, 2014; Available online: www.ior.poznan.pl/plik,2361,kodeks-dobrej-praktyki-ochrony-roslinpdf.pdf (accessed on 9 September 2020).

11. Popp, J.; Peto, K.; Nagy, J. Pesticide productivity and food security. A review. Agron. Sustain. Dev. 2013, 33, 243-255. [CrossRef]

12. Katan, J. Physical and culture methods for the management of soil borne pathogens. Crop. Prot. 2000, 19, 725-731. [CrossRef]

13. Gacek, E.; Głazek, M.; Matyjaszczyk, E.; Pruszyński, G.; Pruszyński, S.; Stobiecki, S. Metody Ochrony w Integrowanej Ochronie Roślin; Wyd. Centrum Doradztwa Rolniczego w Brwinowie: Poznań, Poland, 2016; p. 150.

14. Mitra, A.; Li, Y.; Klämpf, T.; Shimizu, T.; Jeon, J.; Morfill, G.; Zimmermann, J. Inactivation of surface-borne microorganisms and increased germination of seed specimen by cold atmospheric plasma. Food Bioprocess. Technol. 2014, 7, 645-653. [CrossRef]

15. Sauer, J.A.; Shelton, M.D. High temperature controlled atmosphere for post-harvest control of Indian meal moth (Lepidoptera: Pyralidae) on preserved flowers. J. Stored Prod. Res. 2002, 95, 1074-1078. [CrossRef]

16. Zhou, Y.; Deng, L.; Zeng, K. Enhancement of biocontrol efficacy of Pichia membranaefaciens by hot water treatment in postharvest diseases of citrus fruit. Crop Prot. 2014, 63, 89-96. [CrossRef]

17. Wang, M.R.; Cui, Z.H.; Jingwei, L.; Hao, X.Y.; Zhao, L.; Wang, Q.C. In vitro thermotherapy-based methods for plant virus eradication. Plant Methods 2018, 14, 87. [CrossRef] [PubMed]

18. Zhang, Z.; Lee, J.K.; Sivertsen, A.; Skjeseth, G.; Haugslien, S.; Clarke, J.L.; Wang, Q.C.; Blystad, D.R. Low Temperature Treatment Affects Concentration and Distribution of Chrysanthemum Stunt Viroid in Argyranthemum. Front. Microbiol. 2016, 7, 224. [CrossRef] [PubMed] 
19. Mahajan, P.V.; Caleb, O.J.; Singh, Z.; Watkins, C.B.; Geyer, M. Postharvest treatments of fresh produce. Philos. Trans. A Math. Phys. Eng. Sci. 2014, 372. [CrossRef]

20. Mielniczuk, E.; Skwaryło-Bednarz, B. Fusarium Head Blight, Mycotoxins and Strategies for Their Reduction. Agronomy 2020, 10, 509. [CrossRef]

21. Olaimat, A.N.; Holley, R.A. Factors influencing the microbial safety of fresh produce: A review. Food Microbiol. 2012, 32, 1-19. [CrossRef]

22. Carrlee, E. Does low-temperature pest management cause damage? Literature review and observational study of ethnographic artifacts. J. Am. Inst. Conserv. 2003, 42, 141-166. [CrossRef]

23. Streck, N.A.; Schneider, F.M.; Buriol, G.A. Effect of soil solarization on tomato inside plastic greenhouse. Ciência. Rural 1995, 25. [CrossRef]

24. Escamilla, D.; Rosso, M.L.; Zhang, B. Identification of fungi associated with soybeans and effective seed disinfection treatments. Food Sci. Nutr. 2019, 7, 3194-3205. [CrossRef]

25. Woźnica, Z. Herbologia: Podstawy Biologii, Ekologii i Zwalczania Chwastów; Wyd. PWRiL: Poznań, Poland, 2008 ; p. 430.

26. Lima, F.; Vieira, K.; Santos, M.; Mendes de Sauza, P. Effects of Radiation Technologies on Food Nutritional Quality. In Descriptive Food Science; BoD-Books on Demand: Norderstedt, Germany, 2018. [CrossRef]

27. Tabatabaei, F. More About Radioactive Pollution. Health Scope 2012, 1, 99-100. [CrossRef]

28. Costa, H.S.; Robb, K.L.; Wilen, C.A. Field Trials Measuring the Effects of Ultraviolet-Absorbing Greenhouse Plastic Films on Insect Populations. J. Econ. Entomol. 2002, 95, 113-120. [CrossRef] [PubMed]

29. Franco, B.D.G.M.; Landgraf, M. Microbiologia dos Alimentos; Atheneu: São Paulo, Brazil, 1996; p. 182.

30. Ornellas, C.B.D.; Gonçalves, M.P.J.; Silva, P.R.; Martins, R.T. Atitudes do consumidor frente à irradiação de alimentos. Ciência e Tecnol. de Aliment. 2006, 26, 211-213. [CrossRef]

31. Chu, E.H.; Shin, E.J.; Park, H.J.; Jeong, R.D. Effect of Gamma Irradiation on Botrytis cinerea Causing Gray Mold and Cut Chrysanthemum Flowers. Res. Plant Dis. 2015, 21, 193-200. [CrossRef]

32. Abbas, H.; Nouraddin, S.; Reza, S.H.; Iraj, B.; Mohammad, B.; Hasan, Z.; Hossein, A.M.; Hadi, F. Effect of gamma radiation on different stages of Indian meal moth Plodia interpunctella Hübner (Lepidoptera: Pyralidae). Afr. J. Biotechnol. 2011, 10, 4259-4264.

33. Ignatowicz, S. Możliwość Wykorzystania Promieniowania Jonizującego w Kwarantannie Roślin. Mater. Ses. Nauk. Inst. Ochr. Roślin 1992, 32, 80-87.

34. Knipling, E.F. Control of Screw-Worm Fly by Atomic Radiation. Sci. Mon. 1957, 85, 195-202.

35. Oseto, C.Y. Physical Control of Insects; CRC Press LLC: Boca Raton, FL, USA, 2000; p. 76.

36. Pickens, L.G.; Thimijan, R.W. Design Parameters That Affect the Performance of UVemitting Traps in Attracting House Flies (Diptera: Muscidae). J. Econ. Entomol. 1986, 79, 1003-1009. [CrossRef]

37. Schönthaler, J.; Dominik, A. Integrowana Ochrona Roślin w Gospodarstwie; Wyd. Centrum Doradztwa Rolniczego w Brwinowie, Oddział w Radomiu: Radom, Poland, 2012; p. 70.

38. Navarro, S. Modified Atmospheres for the Control of Stored-Product Insects and Mites. In Insect Management for Food Storage and Processing, 2nd ed.; Heaps, W., Ed.; AACC International: Saint Paul, MN, USA, 2006; pp. 101-141. [CrossRef]

39. Nawalny, G.; Herbut, P.; Sokołowski, P. Analiza Techniczna i Kierunki Rozwoju Przechowalni Warzyw i Owoców w Rejonie Skalbmierza; Wyd. PAN: Kraków, Poland, 2014; pp. 217-226.

40. Liu, Y.B. Ultralow oxygen treatment for postharvest control of western flower thrips, Frankiniella occidentalis (Thysanoptera: Thripidae), on iceberg lettuce I. Effects of temperature, time, and oxygen level on insect mortality and lettuce quality. Postharvest Biol. Technol. 2008, 49, 129-134. [CrossRef]

41. Hammer, P.E.; Yang, S.F.; Reid, M.S.; Marois, J.J. Postharvest control of Botrytis cinerea infections on cut roses using fungistatic storage atmospheres. J. Am. Soc. Hort. Sci. 1990, 115, 102-107. [CrossRef]

42. Piwoni, A. Health status of two plantations of tulip near Pulawy and fungi isolated from foliar parts and bulbs. Electron. J. Pol. Agric. Univ. 2007, 10. Available online: http://www.ejpau.media.pl/volume10/issue4/art-07.html (accessed on 12 September 2020).

43. Highland, H.A. Insect resistance of food packages: A review. J. Food Process. Preserv. 2007, 2, 123-129. [CrossRef]

44. Conte, A.; Angiolillo, L.; Mastromatteo, M.; Del Nobile, M.A. Technological Options of Packaging to Control Food Quality; InTech: London, UK, 2013. [CrossRef]

45. Nawrot, J.; Olejarski, P. Alternatywne Metody Zwalczania Owadzich Szkodników Magazynowych; Wyd. Instytut Ochrony Roślin w Poznaniu: Poznań, Poland, 2007; pp. 32-39.

46. Marsh, R.E.; Erickson, W.A.; Salomon, T.P. Bird Hazing and Frightening Methods and Techniques (with Emphasis on Containment Ponds); University of California Davis: Davis, CA, USA, 1991; p. 236.

47. Wiech, K.; Bednarek, A.; Grabowski, M.; Goszczyński, W. Ochrona Roślin bez Chemii; Wyd. Działkowiec: Warszawa, Poland, 2001; pp. 81-85.

48. Streng, A.G. Tables of Ozone Properties. J. Chem. Eng. Data 1961, 6, 431-436. [CrossRef]

49. Rubin, M.B. The History of Ozone: The Schönbein Period, 1839-1868. Bull. Hist. Chem. 2001, 26, 40-56.

50. Gotz, W.; Meetham, A.; Dobson, G. The vertical distribution of ozone in the atmosphere . Proc. Roy. Soc. Lond. A 1934, 145, 416-446. 
51. Tanaka, T.; Morino, Y. Coriolis interaction and anharmonic potential function of ozone from the microwave spectra in the excited vibrational states. J. Mol. Spectrosc. 1970, 33, 538-551. [CrossRef]

52. Nalepa, C. Oxidizing biocides: Properties and applications. In Association of Water Technologies Fall Meeting; Association of Water Technologies (AWT): Traverse City, MI, USA, 1997.

53. Shimanouchi, T. Ozone. NIST Natl. Inst. Stand. Technol. U.S. Dep. Commer. 1972, 6, 993-1102.

54. Ozonek, J. Laboratorium Syntezy Ozonu: Podstawy Procesowe, Pomiary Elektryczne, Ekotechnologie; Wyd. Politechnika Lubelska: Lublin, Poland, 1993; p. 122.

55. Lunin, V.V.; Popovich, M.P.; Tkachenko, S.N. Physical Chemistry of Ozone; Moscow State University: Moscow, Russia, 1998 ; p. 480.

56. Mateer, C.; Heath, D.; Krueger, A. Estimation of total ozone from satellites measurements of backscattered ultraviolet earth radiance. J. Atmosph. Sci. 1971, 28, 1307-1311. [CrossRef]

57. Hoigné, J. The Handbook of Environmental Chemistry; Springer: Berlin, Germany, 1998; Volume 5, Part C; pp. 83-141.

58. Wan-Norafikach, O.; Lee, H.L.; Norazizah, A.; Mohamed-Hafiz, A. Repellency effects of an ozone-producing air purifier against medically important insect vectors. Trop. Biomed. 2016, 33, 396-402.

59. Alternative Disinfectants and Oxidant Guidance Manual; United States Environmental Protection Agency: Washington, DC, USA, April 1999.

60. Biń, A. Zastosowanie ozonu w oczyszczaniu wody i uzdatnianiu ścieków. Pol. Instal. 1995, 6, $28-31$.

61. Bursa, S.; Stanisz-Lewicka, M.; Kicinska, M.; Kosmider, J. Dezodoryzacja Gazow i Ściekow Część 1—Dezodoryzacja na drodze ozonowania; Wyd. Politechniki Szczecinskiej: Szczecin, Poland, 1985.

62. Keivanloo, E.; Namaghi, H.S.; Khoodaparast, M.H.H. Effects of low ozone concentrations and short exposure times on the mortality of immature stages of the Indian meal moth Plodia interpunctella (Lepidoptera: Pyralidae). J. Plant Prot. Res. 2014, 54, 267-271. [CrossRef]

63. Bai, S.; Sugimoto, M.; Yoshida, K. Color Removal of Wastewater by Ozonation. In Proceedings of the 13th Ozone World Congress, Kyoto, Japan, 26-31 October 1997; pp. 37-40.

64. Beltran, F. Theoretical aspects of the kinetics of competitive first reactions of ozone in $\mathrm{O}_{3} / \mathrm{H}_{2} \mathrm{O}_{2}$ and $\mathrm{O}_{3} / \mathrm{UV}$ oxidation process. Ozone Sci. Eng. 1996, 22, 109-127.

65. Levy, R.; Jouvenaz, D.P.; Cromroy, H.L. Tolerance of tyree species if insects to prolonged exposures to ozone. Environ. Entomol. 1974, 3, 184-185. [CrossRef]

66. Xu, L. Use of Ozone to Improve the Safety of Fresh Fruits and Vegetables. Food Technol. Mag. 1999, 53, 10.

67. Takigawa, K.; Ueno, K.; Nagatomo, T.; Mitsugi, F.; Ikegami, T.; Ebihara, K.; Nakamura, N.; Hashimoto, Y.; Yamashita, Y. Experiment of Pest Control with Portable Ozone Mist Device. 2012. Available online: www.ispc-conference.org/ispcproc/ispc2 1/ID136.pdf (accessed on 15 October 2020).

68. Ebihara, K.; Stryczewska, H.; Ikegami, T.; Mitsugi, F.; Pawłat, J. On-site ozone treatment for agricultural soil and related applications. Przegląd Elektrotechniczny 2011, 87, 148-152.

69. Ladányi, M.; Nowinszky, L.; Kiss, O.; Puskás, J.; Szentkirályi, F.; Barczikay, G. Modelling the impast of tropospheric ozone content on light- and pheromone-trapped insects. Appl. Ecol. Environ. 2012, 10, 471-491. [CrossRef]

70. Mendez, F.; Maier, D.; Mason, L.J.; Woloshuk, C.P. Penetration of ozone into columns of stored grains and effects on chemical composition and processing performance. J. Stored Prod. Res. 2003, 39, 33-44. [CrossRef]

71. Hollingsworth, R.G.; Armstrong, J.W. Potential of controlled atmospheres, and ozone fumigation to control thrips and mealybugs on ornamental plants for export. J. Econ. Entomol. 2005, 98, 289-298. [CrossRef]

72. Isikber, A.A.; Athanassiou, C. The use of ozone gas for the control of insects and micro-organisms in stored products. J. Stored Prod. Res. 2014, 64. [CrossRef]

73. Ebihara, K.; Mitsugi, F.; Ikegami, T.; Nakamura, N.; Hashimoto, Y.; Yamashita, Y.; Baba, S.; Stryczewska, H.; Pawłat, J.; Teii, S.; et al. Ozone-mist spray sterilization for pest control in agricultural management. Eur. Phys. J. Appl. Phys. 2013, 61, 2012120420. [CrossRef]

74. Perez, A.G.; Sanz, C.; Rios, J.J.; Olıas, R.; Olıas, J.M. Effects of ozone treatment on postharvest strawberry quality. J. Agr. Food Chem. 1999, 47, 1652-1656. [CrossRef] [PubMed]

75. Tzortzakis, N.; Borland, A.; Singleton, I.; Barnes, J. Impact of atmospheric ozone-enrichment on quality-related attributes of tomatofruit. Postharvest Biol. Technol. 2007, 45, 317-325. [CrossRef]

76. Carletti, L.; Botondi, R.; Moscetti, R.; Stella, E.; Monarca, D.; Cecchini, M.; Massantini, R. Use of ozone in sanitation and storage of fresh fruits and vegetables. J. Food Agric. Environ. 2013, 11, 585-589.

77. Krosowiak, K.; Śmigielski, K.; Dziugan, P. Zastosowania ozonu w przemyśle spożywczym. Przemyst Spożywczy 2007, 11, 26-29.

78. Zambuchini, B.; Giosia, L.; Sturba, M. Study of the ozoneeffect on the shelf-life of minimally processed salad (Review). Postharvest Biol. Tec. 2006, 45, 636-643.

79. Rodgers, S.L.; Cash, J.N.; Siddiq, M.; Ryser, E.T. A comparisonof different chemical sanitizers for inactivatingEscherichia coliO157: H7 andListeria monocytogenesin solution and on apples, lettuce, strawberries, and cantaloupe. J. Food Prot. 2004, 67, 721-731. [CrossRef]

80. Łozowicka, B.; Jankowska, M.; Hrynko, I.; Kaczynski, P. Removal of 16 pesticide residues from strawberries by washing with tap and ozone water, ultrasonic cleaning and boiling. Environ. Monit. Assess. 2016, 188, 51. [CrossRef] 
81. Ong, K.C.; Cash, J.N.; Zabik, M.J.; Siddiq, M.; Jones, A.L. Chlorine and ozone washes for pesticide removal from apples and processed apple sauce. Food Chem. 1996, 55, 153-160. [CrossRef]

82. Beuchat, L.R. Surface disinfection of raw produce. Dairy Food Environ. Sanit. 1992, 12, 69.

83. Chwaszcz, B.; Józefczyk, R.; Bilek, M.; Balawajder, M. Ozonowanie jako metoda przedłużania trwałości przechowalniczej owoców maliny w warunkach niechłodniczych. In Technologiczne Kształtowanie Jakości Żywności, 1st ed.; Wójciak, K.M., Dolatowski, Z.J., Eds.; Wyd. Naukowe PTTŻ: Kraków, Poland, 2015; pp. 15-26.

84. Rice, R.G. Etapy Rozwoju i Aktualne Zastosowania Ozonu w Przetwórstwie Żywności; Zastosowanie Ozonu, Wyd. PAN: Łódź, Poland, 2005; pp. 279-322.

85. Palou, L.; Crisosto, C.H.; Smilanick, J.L.; Adaskaveg, J.E.; Zoffoli, J.P. Effects of continuous 0.3 ppm ozone exposure on decaydevelopment and physiological responses of peaches and table grapesin cold storage. Postharvest Biol. Tec. 2002, 24, 39-48. [CrossRef]

86. Vlassi, E.; Vlachos, P.; Kornaros, M. Effect of ozonation on table grapes preservation in cold storage. J. Food Sci. Technol. 2018, 55. [CrossRef] [PubMed]

87. De Simone, N.; Pace, B.; Grieco, F.; Chimienti, M.; Tyibilika, V.; Santoro, V.; Capozzi, V.; Colelli, G.; Spano, G.; Russo, P. Botrytis cinerea and Table Grapes: A Review of the Main Physical, Chemical, and Bio-Based Control Treatments in Post-Harvest. Foods 2020, 9, 1138. [CrossRef]

88. Mari, M.; Bertolini, P.; Pratella, G.C. Non-conventional methods for the control of post-harvest pear diseases. J. Appl. Microbiol. 2003, 94, 761-766. [CrossRef] [PubMed]

89. Tzortzakis, N.; Singleton, I.; Barnes, J. Impact of low-levelatmospheric ozone-enrichment on black spot and anthracnose rot oftomato fruit. Postharvest Biol. Tec. 2008, 47, 1-9. [CrossRef]

90. Song, J.; Fan, L.; Forney, C.F. Biological Effects of Corona Discharge on Onions in a Commercial Storage Facility. HortTechnology 2000, 10, 608-612. [CrossRef]

91. Pazarlar, S.A.; Cetinkaya, N.A.; Bor, M.B.C.; Ozdemir, F.B. Ozone triggers different defence mechanisms against powdery mildew (Blumeria graminis DC. Speer f. sp. tritici) in susceptible and resistant wheat genotypes. Funct. Plant Biol. 2017, 44, 1016-1028. [CrossRef] [PubMed]

92. Liu, Y.B. Ultralow oxygen treatment for postharvest control of Nasonovia ribisnigri (Homoptera: Aphididae) on iceberg lettuce. J. Econ. Entomol. 2005, 98, 1899-1904. [CrossRef]

93. Tseng, C.C.; Li, C. Inactivation of surface viruses by gaseous Ozone. J. Environ. Health 2008, 70, 56-62.

94. Ignatowicz, S. Skuteczność zabiegów ozonowania w dezaktywacji koronawirusa SARS-CoV-2. Przemyst Spożywczy 2020, 74, 12-18. [CrossRef]

95. Batakliev, T.; Georgiev, V.; Anachkov, M.; Rakovsky, S.; Zaikov, G.E. Ozone decomposition. Interdiscip. Toxicol. 2014, 7, 47-59. [CrossRef]

96. Białoszewski, D.; Bocian, E.; Tyski, S. Ozonoterapia Oraz Zastosowanie Ozonu w Dezynfekcji; Wyd. Warszawski Uniwersytet Medyczny: Warszawa, Poland, 2012; pp. 177-183.

97. Fiscus, E.L.; Booker, F.L.; Burkey, K.O. Crop responses to ozone: Uptake, modes of action, carbon assimilation and partitioning. Plant Cell Environ. 2005, 28, 997-1011. [CrossRef]

98. Cape, J.N. Surface ozone concentrations and ecosystem health: Past trends and a guide to future protections. Sci. Total Environ. 2008, 400, 257-269. [CrossRef] [PubMed]

99. Baciak, M.; Warmiński, K.; Bęś, A. Oddziaływanie wybranych gazowych zanieczyszczeń powietrza na rośliny drzewiaste. Leśne Prace Badaw. 2015, 76, 401-409. [CrossRef]

100. Hunowá, I.; Novotný, R.; Uhlírová, H.; Vráblík, T.; Horálek, J.; Lomský, B.; Srámek, V. The impact of ambient ozone on mountain spruce forests in the Czech Republic as indicated by malondialdehyde. Environ. Pollut. 2010, 158, 2393-2401. [CrossRef] [PubMed]

101. Wagg, S.; Mills, G.; Hayes, F.; Wilkinson, S.; Cooper, D.; Daviies, W.J. Reduced soil water availability did not protect two competing grassland species from the negative effects of increasing background ozone. Environ. Pollut. 2012, 1655, 91-99. [CrossRef] [PubMed]

102. Brown, T.L.; Le May, H.E.; Bursten, B.E., Jr.; Burdge, J.R. Chemistry: The Central Science, 9th ed.; Pearson College: Hoboken, NJ, USA, 2002; p. 1152.

103. Chen, F.; Chang, J. Lecture Notes on Principles of Plasma Processing; Springer: New York, NY, USA, $2003 ;$ p. 208.

104. Pawłat, J.; Starek, A.; Sujak, A.; Terebun, P.; Kwiatkowski, M.; Budzeń, M.; Andrejko, D. Effects of atmospheric pressure plasma jet operating with DBD on Lavatera thuringiaca L. seeds' germination. PLoS ONE 2018, 13, e0194349. [CrossRef]

105. Langmuir, I. Scattering of Electrons in Ionized Gases. Phys. Rev. 1925, 26, 585. [CrossRef]

106. Brisset, J.-L.; Pawłat, J. Chemical effects of air plasma species on aqueous solutes in direct and delayed exposure modes: Discharge, post-discharge and plasma activated water. Plasma Chem. Plasma Process. 2015, 36, 355-381. [CrossRef]

107. Pawłat, J. Electrical Discharges in Humid Environments Generators, Effects, Application; Wyd. Politechnika Lubelska: Lublin, Poland, 2013; p. 142.

108. Jablonowski, H.; Woedtke, T. Research on plasma medicine-relevant plasma-liquid interaction: What happened in the past five years? Clin. Plasma Med. 2015, 3, 42-52. [CrossRef]

109. Kogelschatz, U. Silent Discharges and Their Applications-Invited Lecture. In Proceedings of the 10th International Conference on Gas Discharges and Their Applications, Swansea, UK, 13-18 September 1992. 
110. Kogelschatz, U. Dielectric-Barrier Discharges: Their History, Discharge Physics, and Industrial Applications. Plasma Chem. Plasma Process. 2003, 23, 1-46. [CrossRef]

111. Kogoma, M.; Okazaki, S. Raising of ozone formation efficiency in a homogenous glow discharge plasma at atmospheric pressure. J. Phys. D Appl. Phys. 1994, 27, 1985-1987. [CrossRef]

112. Pietch, G. Gas Discharges in Ozone Generators. In Proceedings of the Regional Conference on Ozone Generation and Application to Water and Wastewater Treatment, Moscow, Russia, 1988; pp. 13-28.

113. Haacke, M.; Pietsch, G. Some Features of Dielectric Barrier Discharges. In Proceedings of the XIII International Conference on Gas Discharges and Their Applications, Glasgow, UK, 3-8 September 2000; Department of Electronic and Electrical Engineering, University of Strathclyde: Glasgow, UK, 2000; pp. 267-270.

114. Gribalov, V.; Murata, T.; Pietsch, G. Modeling of the discharge development in coplanar arrangements. In Proceedings of the XIII International Conference on Gas Discharges and Their Applications, Glasgow, UK, 3-8 September 2000; Department of Electronic and Electrical Engineering, University of Strathclyde: Glasgow, UK, 2000; pp. 275-278.

115. Čech, J.; Hanusová, J.; St'ahel, P.; Černák, M. Diffuse Coplanar Surface Barrier Discharge in Artificial Air: Statistical Behaviour of Microdischarges. Open Chem. 2015, 13, 528-540. [CrossRef]

116. Tendero, C.; Tixier, C.; Tristant, P.; Desmaison, J.; Leprince, P. Atmospheric Pressure Plasmas: A Review. Spectrochim. Acta Part B 2006, 61, 2-30. [CrossRef]

117. Kim, C.; Bahn, J.; Lee, S.; Kim, G.; Jun, S.; Lee, K.; Baek, S. Induction of cell growth arrest by atmospheric non-thermal plasma in colorectal cancer cells. J. Biotechnol. 2010, 150, 530-538. [CrossRef] [PubMed]

118. Pawłat, J. Atmospheric pressure plasma jet for decontamination purposes . Eur. Phys. J. Appl. Phys. 2013, 61, 2012120431. [CrossRef]

119. Raniszewski, G.; Wiak, S.; Pietrzak, L.; Szymanski, L.; Kolacinski, Z. Influence of Plasma Jet Temperature Profiles in Arc Discharge Methods of Carbon Nanotubes Synthesis. Nanomaterials 2017, 7, 50. [CrossRef]

120. Hensel, K.; Kučerová, K.; Tarabová, B.; Janda, M.; Machala, Z. Effects of air transient spark discharge and helium plasma jet on water, bacteria, cells, and biomolecules. Biointerphases 2015, 10, 029515. [CrossRef]

121. Pawłat, J.; Starek, A.; Sujak, A.; Kwiatkowski, M.; Terebun, P.; Budzeń, M. Effects of atmospheric pressure plasma generated in GlidArc reactor on Lavatera thuringiaca L. seeds' germination. Plasma Process. Polym. 2017, 15, 201700064. [CrossRef]

122. Pawłat, J.; Terebun, P.; Kwiatkowski, M.; Tarabová, B.; Koval'ová, Z.; Kučerová, K.; Machala, Z.; Janda, M.; Hensel, K. Evaluation of Oxidative Species in Gaseous and Liquid Phase Generated by Mini-Gliding Arc Discharge. Plasma Chem. Plasma Process. 2019, 39, 627-642. [CrossRef]

123. Moisan, M.; Barbeau, J.; Crevier, M.-C.; Pelletier, J.; Philip, N.; Saoudi, B. Plasma sterilization. Methods and mechanisms. Pure Appl. Chem. 2002, 74, 349. [CrossRef]

124. Kyzek, S.; Holubova, L.; Medvecka, V.; Zahoranova, A.; Ševčovičova, A.; Galova, E. Genotoxic effect of low temperature plasma treatment on plant seeds. Toxicol. Lett. 2017, 119. [CrossRef]

125. Wiktor, A.; Śledź, M.; Nowacka, M.; Witrowa-Rajchert, D. Możliwości zastosowania niskotemperaturowej plazmy w technologii żywności. Żywność Nauka Technol. Jakość 2013, 5, 5-14.

126. Dzimitrowicz, A.; Jamróz, P.; Nowak, P. Sterylizacja za Pomoca Niskotemperaturowej Plazmy, Generowanej w Warunkach Ciśnienia Atmosferycznego; Wyd. Politechnika Wrocławska: Wrocław, Poland, 2014; pp. 195-200.

127. Brelles, M.G. Biological and Environmental Application of Gas Discharge Plasmas; California State Polytechnic University: Pomona, CA, USA, 2012; p. 282.

128. Belkind, A.; Gershman, S. Plasma Cleaning and Surface. From Vacuum Technology \& Coating. 2008. Available online: https://www.researchgate.net/publication/284486745_Plasma_cleaning_of_surfaces (accessed on 5 December 2020).

129. Pawłat, J.; Terebun, P.; Kwiatkowski, M.; Diatczyk, J. RF atmospheric plasma jet surface treatment of paper. J. Phys. D App. Phys. 2016, 49, 374001. [CrossRef]

130. Melamies, I.A. Pretreatment of LED lights. Turn Future Adhes. 2016, 13, 15-18.

131. Eliáš, M.; Kloc, P.; Jašek, O.; Mazánková, V.; Trunec, D.; Hrdý, D.; Zajíčková, L. Atmospheric pressure barrier discharge at high temperature: Diagnostics and carbon nanotubes deposition. J. Appl. Phys. 2015, 117, 103301. [CrossRef]

132. Raniszewski, G. Arc discharge plasma for effective carbon nanotubes synthesis. In Proceedings of the International Conference on Electromagnetic Devices and Processes in Environment Protection with Seminar Applications of Superconductors (ELMECO \& AoS), Lublin, Poland, 3-6 December 2017. [CrossRef]

133. Prochazka, M.; Blahova, L.; Krcma, F. Barrier $\mathrm{SiO}_{2}$-like coatings for archaeological artefacts preservation. J. Phys. Conf. Ser. 2016, 768, 012013. [CrossRef]

134. Mazánková, V.; St’ahel, P.; Matoušková, P.; Brablec, A.; Čech, J.; Prokeš, L.; Buršíková, V.; Stupavská, M.; Lehocký, M.; Ozaltin, K.; et al. Atmospheric Pressure Plasma Polymerized 2-Ethyl-2-oxazoline Based Thin Films for Biomedical Purposes. Polymers 2020, 12, 2679. [CrossRef]

135. Makhneva, E.; Barillas, L.; Weltmann, K.-D.; Fricke, K. Stability of oxygen-rich plasma-polymerized coatings in aqueous environment editors-pick. Biointerphases 2020, 15, 061001. [CrossRef]

136. Pawłat, J.; Terebun, P.; Kwiatkowski, M.; Hensel, K.; Michala, Z.; Kovalova, Z.; Kučerová, K.; Tarabová, B.; Janda, M.; Starek, A.; et al. Atmospheric pressure plasmas for agriculture, medicine and surface technology. In Proceedings of the 33rd International Conference on Phenomena in Ionized Gases (ICPIG 2017), Estoril, Portugal, 9-14 July 2017. 
137. Samoń, R.; Czapiński, J.; Grządziel, J.; Płonka, M.; Pawłat, J.; Diatczyk, J. Ocena działania bakteriobójczego niskotemperaturowej plazmy nierównowagowej generowanej w reaktorze RF. Eur. J. Med. Technol. 2014, 2, 17-26.

138. Šera, B.; Spatenka, P.; Šery, M.; Vrchotova, N.; Hruskova, I. Influence of Plasma Treatment on Wheat and Oat Germination and Early Growth. IEEE Trans. Plasma Sci. 2010, 38, 2963-2974. [CrossRef]

139. Kordas, L.; Pusz, W.; Czapka, T.; Kacprzyk, R. The Effect of Low-Temperature Plasma on Fungus Colonization of Winter Wheat Grain and Seed Quality. Pol. J. Environ. Stud. 2015, 24, 379-384.

140. Matra, K. Atmospheric non-thermal argon-oxygen plasma for sunflower seedling growth improvement. Jpn. J. Appl. Phys. 2018, 57, 1S. [CrossRef]

141. Perez, S.; Biondi, E.; Laurita, R.; Proto, M.; Sarti, F.; Gherardi, M.; Bertaccini, A.; Colombo, V. Plasma activated water as resistance inducer against bacterial leaf spot of tomato. PLoS ONE 2019, 14, e0217788. [CrossRef] [PubMed]

142. Nishime, T.M.C.; Wannicke, N.; Horn, S.; Weltmann, K.-D.; Brust, H. A Coaxial Dielectric Barrier Discharge Reactor for Treatment of Winter Wheat Seeds. Appl. Sci. 2020, 10, 7133. [CrossRef]

143. Niemira, B.; Sites, J. Cold plasma inactivates Salmonella stanley and Escherichia coli O157:H7 inoculated on golden delicious Apples. J. Food Prot. 2008, 71, 1357-1365. [CrossRef]

144. Hayashi, N.; Yagyu, Y. Applications of High Voltage and Plasma to Agricultural Products. J. Inst. Electr. Eng. Jpn. 2016, 136, 798-801. [CrossRef]

145. Butscher, D.; Zimmermann, D.; Schuppler, M.; von Rohr, R.P. Plasma inactivation of bacterial endospores on wheat grains and polymeric model substrates in a dielectric barrier discharge. Food Control. 2016, 60, 636-645. [CrossRef]

146. Jiang, J.; Lu, Y.; Li, J.; Li, L.; He, H.; Shao, H.; Dong, Y. Effect of seed treatment by cold plasma on the resistance of tomato to Ralstonia solanacearum (Bacterial Wilt). PLoS ONE 2014, 9, 1-6. [CrossRef]

147. Baier, M.; Gorgen, M.; Ehlbeck, J.; Knorr, D.; Herppich, W.B.; Schlueter, O. Non-thermal atmospheric pressure plasma: Screening for gentle process conditions and antibacterial efficiency on perishable fresh produce. Innov. Food Sci. Emerg. Technol. 2014, 22, 147. [CrossRef]

148. Vaze, N.D.; Park, S.; Brooks, A.D.; Fridman, A.; Joshi, S.G. Involvement of multiple stressors induced by non-thermal plasmacharged aerosols during inactivation of airborne bacteria. PLoS ONE 2017, 12, e0171434. [CrossRef]

149. Kirkpatrick, M.J.; Dodet, B.; Odic, E. Atmospheric Pressure Humid Argon DBD Plasma for the Application of SterylizationMeasurement and Simulation of Hydrogen, Oxygen, and Hydrogen Peroxide Formation. Int. J. Plasma Environ. Sci. Technol. 2007, 1, 96-101.

150. Dasan, B.G.; Boyaci, I.H. Effect of Cold Atmospheric Plasma on Inactivation of Escherichia coli and Physicochemical Properties of Apple, Orange, Tomato Juices, and Sour Cherry Nectar. Food Bioprocess. Technol. 2017, 11. [CrossRef]

151. Skryplonek, K. Zimna plazma jako niekonwencjonalna metoda utrwalania żywności. Inżynieria Przetwórstwa Spożywczego 2016, 4 , 28-33.

152. Starek, A.; Pawłat, J.; Chudzik, B.; Kwiatkowski, M.; Terebun, P.; Sagan, A.; Andrejko, D. Evaluation of selected microbial and physicochemical parameters of fresh tomato juice after cold atmospheric pressure plasma treatment during refrigerated storage. Sci. Rep. 2019, 9, 8407. [CrossRef] [PubMed]

153. Dzimitrowicz, A.; Jamroz, P.; Cyganowski, P.; Bielawska-Pohl, A.; Klimczak, A.; Pohl, P. Application of cold atmospheric pressure plasmas for high-throughput production of safe-to-consume beetroot juice with improved nutritional quality. Food Chem. 2020, 336, 127635. [CrossRef]

154. Daeschlein, G.; Scholz, S.; von Woedke, T.; Niggemeier, M.; Kindel, E.; Brandenburg, R.; Weltman, K.D.; Jürgen, M. In Vitro Killing of Clinical Fungal Strains by Low-Temperature Atmospheric-Pressure Plasma Jet. IEEE Trans. Plasma Sci. 2011, 39, 815-821. [CrossRef]

155. Von Woedtke, T.; Metelmann, H.-R.; Weltmann, K.-D. Clinical Plasma Medicine: State and Perspectives of in VivoApplication of Cold Atmospheric Plasma. Contrib. Plasma Phys. 2014, 54, 104-117. [CrossRef]

156. Liguori, A.; Bigi, A.; Colombo, V.; Focarete, M.; Gherardi, M.; Gualandi, C.; Oleari, M.; Panzavolta, S. Atmospheric Pressure Non-Equilibrium Plasma as a Green Tool to Crosslink Gelatin Nanofibers. Sci. Rep. 2016, 6, 38542. [CrossRef]

157. Canal, C.; Fontelo, R.; Hamouda, I.; Guillem-Martia, J.; Cvelbar, U.; Ginebra, M. Plasma-induced selectivity in bone cancer cells Heath. Free Radic. Biol. Med. 2017, 110, 72-80. [CrossRef]

158. Przekora, A.; Pawlat, J.; Terebun, P.; Duday, D.; Canal, C.; Hermans, S.; Audemar, M.; Labay, C.; Thomann, J.; Ginalska, G. The effect of low temperature atmospheric nitrogen plasma on MC3T3-E1 preosteoblast proliferation and differentiation in vitro. $J$. Phys. D Appl. Phys. 2019, 52, 275401. [CrossRef]

159. Tyczkowska-Sieroń, E.; Kapica, R.; Markiewicz, J.; Tyczkowski, J. Linear Microdischarge Jet for Microbiological Applications. Plasma Med. 2018, 8. [CrossRef]

160. Siciliano, I.; Spadaro, D.; Prelle, A.; Vallauri, D.; Cavallero, M.C.; Galibardi, A.; Gullino, M.L. Use of Cold Atmospheric Plasma to Detoxify Hazelnuts from Aflatoxins. Toxins 2016, 26, 125. [CrossRef] [PubMed]

161. Yeung, A.W.K.; Tzvetkov, N.T.; Jóźwik, A.; Horbanczuk, O.K.; Polgar, T.; Pieczynska, M.D.; Sampino, S.; Nicoletti, F.; BerindanNeagoe, I.; Battino, M.; et al. Food toxicology: Quantitative analysis of the research field literature. Int. J. Food Sci. Nutr. 2019. [CrossRef] [PubMed] 
162. Lee, H.; Yong, H.I.; Kim, H.J.; Choe, W.; Yoo, S.J.; Jang, E.J.; Jo, C. Evaluation of the microbiological safety, quality changes, and genotoxicity of chicken breast treated with flexible thin-layer dielectric barrier discharge plasma. Food Sci. Biotechnol. 2016, 25, 1189-1195. [CrossRef]

163. Wolny-Koładka, K.; Pawłat, J.; Terbun, P.; Kwiatkowski, M.; Diatczyk, J. Ocena możliwości zastosowania plazmy niskotemperaturowej w celu higienizacji zmieszanych odpadów komunalnych służących do produkcji paliwa alternatywnego. Przeglą Elektrotechniczny 2017, 93, 209-213. [CrossRef]

164. Laskowska, M.; Bogusławska-Wąs, E.; Kowal, P.; Hołub, M.; Dabrowski, W. Skuteczność Stosowania Niskotemperaturowej Plazmy w Mikrobiologii i Medycynie; Wyd. ZUT: Szczecin, Poland, 2016; pp. 172-181.

165. Hawrylak-Nowak, B.; Dresler, S.; Matraszek-Gawron, R.; Oszczęda, R.; Pogorzelec, M. The Water Treated with Low-Frequency Low-Pressure Glow Plasma Enhances the Phytoavailability of Selenium and Promotes The Growth of Selenium-Treated Cucumber Plants. Acta Sci. Pol. Hortorum Cultus 2018, 17, 109-116. [CrossRef]

166. Mystkowska, J.; Dąbrowski, J.R.; Kowal, K.; Niemirowicz, K.; Car, H. Physical and chemical properties of deionized water and saline treated with low-pressure and low-temperature plasma. Chemik 2013, 67, 722-724.

167. Saberi, M.; Modarres-Sanavy, S.A.M.; Zare, R.; Ghomi, H. Amelioration of Photosynthesis and Quality of Wheat under Nonthermal Radio Frequency Plasma Treatment. Sci. Rep. 2018, 8, 11655. [CrossRef]

168. Randeniya, L.K.; de Groot, G.J.J.B. Non-Thermal Plasma Treatment of Agricultural Seeds for Stimulation of Germination, Removal of Surface Contamination and Other Benefits: A Review. Plasma Process. Polym. 2015, 12, 608-623. [CrossRef]

169. Ling, L.; Jiangang, L.; Minchong, S. Improving Seed Germination and Peanut Yields by Cold Plasma Treatment. Plasma Sci. Technol. 2016, 18, 1027-1033. [CrossRef]

170. Da Silva, D.L.S.; De Lima Farias, M.; De Oliveira Vitoriano, J.; Alves Junior, C.; Torres, S.B. Use of Atmospheric Plasma in Germination of Hybanthus calceolaria (L.) Schulze-Menz Seeds. Rev. Caatinga 2018, 31, 632-639. [CrossRef]

171. Śliwka, M. Wykorzystanie Biostymulacji Laserowej Roślin do Zwiększenia Przyrostu ich Biomasy Oraz Zdolności Bioremediacyjnych Obieg Pierwiastków w Przyrodzie; Wyd. Instytut Ochrony Środowiska: Warszawa, Poland, 2005.

172. Osman, Y.A.H.; El Tobgy, K.M.K.; El Sherbini, E.S.A. Effect of Laser Radiation Treatments on Growth, Yield and Chemical Constituents of Fennel and Coriander Plants. J. Appl. Sci. Res. 2009, 5, 244-252.

173. Jiang, J.; Li, J.; Dong, Y. Effect of cold plasma treatment on seedling growth and nutrient absorption of tomato. Plasma Sci. Technol. 2018, 20. [CrossRef]

174. Puač, N.; Škoro, N.; Spasić, K.; Živković, S.; Milutinović, M.; Malović, G.; Petrović, Z.L. Activity of catalase enzyme in Paulownia tomentosa seeds during the process ofgermination after treatments with low pressure plasma and plasma activated water. Plasma Process. Polym. 2018, 15, e1700082. [CrossRef]

175. Bormashenko, E.; Shapira, Y.; Grynyov, R.; Whyman, G.; Bormashenko, J.; Drori, E. Interaction of cold radiofrequency plasma with seeds of beans (Phaseolus vulgaris). J. Exp. Bot. 2015, 66, 4013-4021. [CrossRef] [PubMed]

176. Li, L.; Guo, H.; Zong, J. Influence of low-vacuum helium cold plasma pre-treatment on the rooting and root growth of zoysiagrass (Zoysia Willd.) stolon cuttings. Plasma Sci. Technol. 2019, 21, 055504. [CrossRef]

177. Tivendale, N.; Cohen, J.D. Analytical History of Auxin. J. Plant Growth Regul. 2015, 34, 708-722. [CrossRef]

178. Jerzy, M.; Krzymińska, A. Rozmnażanie Wegetatywne Roślin Ozdobnych; Wyd. PWRiL: Poznań, Poland, 2005 ; pp. 1-132.

179. Rout, G.R. Effect of auxins on adventitious root development from single node cuttings of Camellia sinensis (L.) Kuntze and associated biochemical changes. Plant Growth Regul. 2006, 48, 111-117. [CrossRef]

180. Szabó, V.; Magyar, L.; Hrotkó, K. Effect of leaf spray treatments on rooting and quality of Prunus mahaleb (L.) Cuttings. Acta Sci. Pol. Hortorum Cultus 2016, 15, 77-87.

181. Woźniak, M.; Gałązka, A. Mikrobiom ryzosfery i jego korzystny wpływ na rosliny-Aktualna wiedza i perspektywy. Post. Mikrobiol. 2019, 58, 59-69. [CrossRef] 